\title{
Prevention or delay of Type 1 (insulin-dependent) diabetes mellitus in children using nicotinamide
}

\author{
R. B. Elliott ${ }^{1}$ and H.P. Chase ${ }^{2}$ \\ ${ }^{1}$ Department of Paediatrics, School of Medicine, Auckland, New Zealand and ${ }^{2}$ Barbara Davis Center for Childhood Diabetes, \\ Department of Paediatrics, University of Colorado Health Sciences Center, Denver, Colorado, USA
}

Summary. A controlled trial of oral nicotinamide to prevent the onset of diabetes mellitus in high risk children was conducted in two centres. The selection criteria were age less than 16 years, islet cell antibody $\geq 80 \mathrm{IUs}$, and first phase insulin release $<5$ th percentile. All of eight untreated control subjects have developed diabetes, whereas only 1 of 14 treated children has diabetes to date. This data suggests that nicotinamide has an effect in preventing Type 1 (insulindependent) diabetes and that randomized controlled studies are now indicated.

Key words: Nicotinamide, Type 1 (insulin-dependent diabetes mellitus, pre-Type 1 diabetes, islet-cell antibody, intravenous glucose tolerance test.
The onset of Type 1 (insulin-dependent) diabetes mellitus is preceded for many years by the appearance of islet cell antibodies (ICA) [1-4]. High levels of ICA in first degree relatives are followed inevitably by diabetes [2]. In the progression towards diabetes, first phase insulin release (FPIR) is progressively impaired and is a measure of progressive loss of pancreatic islet Beta-cell function [4,5].

Nicotinamide has been shown to prevent diabetes in a non-obese-diabetes (NOD) strain of mice when given by injection [6] or in the diet [7], but is less effective in reversing the disease when given after hyperglycaemia is present [6]. It is not effective in preventing diabetes in the Bio Breeding (BB) rat [8]. The latter appears to apply when nicotinamide is used after the clinical onset of Type 1 diabetes in humans [9-11], particularly in children where it has not been helpful [12]. We therefore decided to study the effects of nicotinamide on a group of children who were first degree relatives of subjects with Type 1 diabetes, deemed at high risk of developing diabetes because of the presence of high levels of ICA and impaired FPIR.

\section{Subjects and methods}

\section{Subjects}

In Denver, 562 children ( $<16$ years of age) who were first degree relatives of subjects with Type 1 diabetes were screened for ICA. All children with ICAs were further selected by the presence of ICA le- vels of 80 or more IUs and impaired FPIR that were $<5$ th percentile $\left(<67 \mathrm{mU} / 1^{5}\right)$. Those whose $\mathrm{HbA}_{1}$ levels were initially elevated beyond the normal range were excluded. Insulin autoantibodies (IAA) were measured initially in most subjects. The first consecutive eight subjects meeting these criteria were not treated so that the natural history of the evolution of clinical diabetes could be studied. All eight were of Anglo descent and are a part of the Denver family study $[4,13]$. Where possible, FPIR was then measured at least annually. Subsequent children were similarly studied, but treated with nicotinamide (see below). In the treated group (Table 1), subject 12 was of half-Hispanic/half-Anglo descent and subject 8 was of halfOriental/half-Anglo descent. All other Denver subjects were of Anglo background.

In Auckland, all children $(n=10)$ were selected from a group of 1500 first degree relatives studied as above, using the identical selection criteria as in Denver, i.e. age less than 16 years, ICA $\geq 80 \mathrm{IU}$, and FPIR $<5$ th percentile. All Auckland children were of Anglo descent.

All of the treated children from both sites were treated with oral nicotinamide $\left(150-300 \mathrm{mg} \cdot\right.$ year of $\mathrm{age}^{-1} \cdot \mathrm{day}^{-1}$ with a maximum dose of $3.0 \mathrm{~g} /$ day using a slow release preparation; Innovite; Tigard, Ore., USA) given twice a day. The period of treatment (Table 1) was uninterrupted in all cases. Subjects were followed-up with repeated measurements of FPIR as above.

\section{Methods}

Islet cell antibodies were determined by an indirect immunofluorescence technique in Denver [4] and by a modification of this technique in Auckland [14]. Both laboratories participate in the International ICA proficiency programme and have validity, consistency, sensitivity and specificity of $>95 \%$ at all levels 
Table 1. a) Untreated group

\begin{tabular}{|c|c|c|c|c|c|c|c|}
\hline & $\begin{array}{l}\text { Age } \\
\text { years }\end{array}$ & $\begin{array}{l}\text { ICA } \\
\text { (IU) }\end{array}$ & $\begin{array}{l}\text { FPIR } \\
\mathrm{mu} / \mathrm{l}\end{array}$ & $\begin{array}{l}\mathrm{IAA} \\
(\mu \mathrm{U} / 1)\end{array}$ & $\begin{array}{l}\text { Time to } \\
\text { diabetes } \\
\text { (months) }\end{array}$ & $\begin{array}{l}\text { FPIR } \\
\text { at } \\
1 \text { year }\end{array}$ & $\begin{array}{l}\text { FPIR } \\
\text { at } \\
2 \text { year }\end{array}$ \\
\hline & 5 & $>80$ & 39 & - & 4 & - & - \\
\hline & 6 & $>80$ & 35 & 964 & 21 & - & - \\
\hline & 15 & $>80$ & 47 & 158 & 11 & - & - \\
\hline & 7 & $>80$ & 43 & 237 & 57 & 61 & 56 \\
\hline & 4 & $>80$ & 29 & 60 & 14 & 3.5 & - \\
\hline & 13 & $>80$ & 15 & 0 & 3 & - & $\ldots$ \\
\hline & 15 & $>80$ & 37 & 20 & 21 & - & - \\
\hline & 6 & $>80$ & 4 & 30 & 4 & - & - \\
\hline $\begin{array}{l}\text { Mean } \\
\text { (range) }\end{array}$ & 8.9 & $\begin{array}{c}>80 \\
-\end{array}$ & $\begin{array}{l}31 \\
(4-47)\end{array}$ & $\overline{(0-964)}$ & $\begin{array}{l}17 \\
(3-57)\end{array}$ & - & - \\
\hline \multicolumn{8}{|c|}{ b) Treated group. } \\
\hline $\begin{array}{l}\text { Subject } \\
\text { number }\end{array}$ & Age & ICA & FPIR & IAA & $\begin{array}{l}\text { Duration } \\
\text { of treat- } \\
\text { ment }\end{array}$ & $\begin{array}{l}\text { FPIR } \\
\text { at } \\
1 \text { year }\end{array}$ & $\begin{array}{l}\text { FPIR } \\
\text { at } \\
2 \text { year }\end{array}$ \\
\hline 1 & 8 & 320 & 66 & 14 & 30 & 83 & - \\
\hline 2 & 1 & 80 & 44 & 176 & 12 & - & - \\
\hline 3 & 3 & 80 & 47 & 3 & 27 & 79 & 128 \\
\hline 4 & 5 & 160 & 56 & 40 & 26 & 98 & 72 \\
\hline 5 & 4 & 160 & 12 & 92 & 24 & 32 & - \\
\hline 6 & 6 & 80 & 15 & 18 & 17 & 14 & - \\
\hline 7 & 8 & 160 & 39 & 6 & 13 & - & - \\
\hline 8 & 6 & 1280 & 43 & 15 & 11 & - & - \\
\hline 9 & 10 & 160 & 14 & 24 & 2 & - & - \\
\hline 10 & 2 & 320 & 26 & 64 & 5 & - & - \\
\hline 11 & $12^{b}$ & $>80$ & 24 & 119 & 26 & 35 & 24 \\
\hline 12 & $8^{b}$ & $>80$ & 21 & 229 & 18 & 18 & - \\
\hline 13 & $6^{\mathrm{b}}$ & 160 & 27 & - & 6 & - & - \\
\hline 14 & $10^{\mathrm{a}, \mathrm{b}}$ & $>80$ & 3 & 137 & 24 & 0 & $7^{\mathrm{a}}$ \\
\hline $\begin{array}{l}\text { Mean } \\
\text { (range) }\end{array}$ & $\begin{array}{c}6.3 \\
(1-12)\end{array}$ & $\begin{array}{c}>80 \\
-\end{array}$ & $\begin{array}{l}31 \\
(3-66)\end{array}$ & $\overline{(3-229)}$ & $\begin{array}{l}17 \\
(2-30)\end{array}$ & - & - \\
\hline
\end{tabular}

a developed diabetes in 25 th month; ${ }^{b}$ treated subjects from Denver

ICA = islet cell antibodies; FPIR = first phase insulin response; IAA $=$ insulin autoantibody

and of $100 \%$ at levels of 80 IUs. Thus, the two methods are comparable.

First phase insulin release was conducted in both centres as follows: dextrose, $0.5 \mathrm{~g} / \mathrm{kg}$ body weight, was injected intravenously over 2-3 min and blood drawn for serum glucose and insulin levels before the injection and at precisely one and three min after completing the dextrose infusion. The sum of these two insulin levels minus the fasting level gives the FPIR.

The insulin assay was standardized between the two laboratories and thus the selection level $(<67 \mathrm{mu} / \mathrm{l}$ ) was comparable.

IAAs were measured as described by Ziegler et al. [15] and standardized to the Boston method by serum exchange (courtesy Dr. G. Eisenbarth, Joslin Clinic, Boston, Mass., USA). Levels $>39 \mu \mathrm{U} / \mathrm{l}$ are considered abnormal [15].

Both centres had approval from their relevant human subjects ethical committees for this study.

Statistical analysis

Life table analysis was determined by the method of Cox and Oaken [16], with statistical significance determined by the Log Rank test, the Wilcoxon test, and the Likelihood Ratio test.

\section{Results}

The data for the two groups, untreated $(n=8)$ and nicotinamide-treated $(n=14)$ for age, initial ICA, FPIR, and IAA are shown in Table 1. Of the individuals completing 1 year of follow-up, four of eight in the untreated and none of nine in the treated group developed diabetes ( $p<0.03$; Fisher Exact test). Of those completing 2 years of follow-up, seven of eight in the untreated and none of six in the treated group had developed diabetes $(p<0.002$; Fisher Exact test). Beyond that time, one of the 14 treated individuals has developed diabetes, and the last of the untreated group has done so. Thus, eight of eight in the untreated group and 1 of 14 in the treated group have the disease $(p<0.00004$; Fisher Exact test $)$. The mean time for the development of diabetes in the untreated group was 17 months. In contrast, none of the treated subjects had developed diabetes after the mean treatment period of 17 months.

Significant differences were found between the untreated and the treated groups (Fig. 1) in the life-table analysis $(p<0.001)$ using a Log-Rank test [16]. Other tests (the Wilcoxon and the Likelihood Ratio test [16]) confirmed a similar level of significance.

The one treated individual who developed diabetes in the 25 th month after commencing treatment had the lowest initial FPIR ( $3 \mathrm{mU} / 1$ ) found in both groups. In the treated group the FPIR 1 year after starting nicotinamide correlated with the initial response, with an overall improvement most marked in those with the higher initial response (Table 1).

\section{Discussion}

Nicotinamide has been shown to be effective in diminishing the occurrence of clinical diabetes in the pre-diabetic female NOD mouse, where the Beta-cell destructive process is assumed to be autoimmune $[6,7]$. Nicotinamide

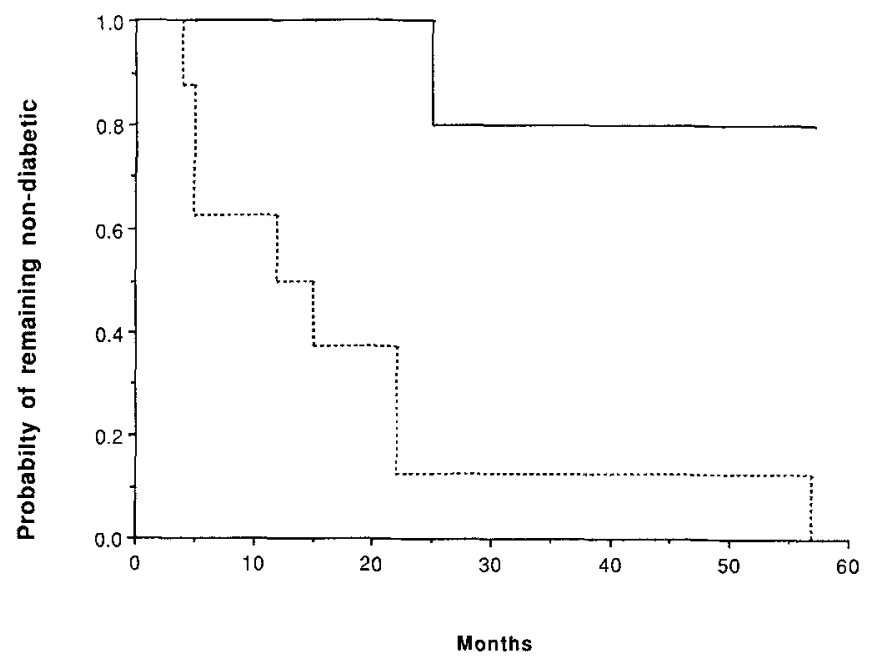

Fig. 1. Product limit survival estimates for control (---.-) and nicotinamide-treated $(-)$ groups. Results were significantly different at $p<0.001$ using the Log Rank, Wilcoxon or Likelihood Ratio tests [16] 
inhibits poly (ADP-ribose) synthetase [6] and, at high concentrations, can act as a free radical scavenger [17]. Pre-treatment with nicotinamide prevents the decrease in proinsulin synthesis in islets from rats treated with alloxan or streptozotocin [18]. It also inhibits the activated macrophage killing of Beta cells in vitro [19], and the expression of Class $2 \mathrm{MHC}$ on Beta cells caused by the cytokines, tumour necrosis factor (TNF) and $\delta$-interferon [20]. These are all processes thought to be part of the immune-mediated destruction of Beta cells found in the human disease.

Although nicotinamide has been postulated as a cocarcinogen in animals [21], there was no evidence of endocrine tumours after 450 days of high-dose nicotinamide treatment in $\mathrm{BB}$ rats [8]. We are unaware of any toxicity reported from nicotinamide in the human other than transient liver enzyme changes and jaundice when a bottle of tablets was swallowed in a suicide gesture. In 35 newly-diagnosed children with Type 1 diabetes given nicotinamide on a double-blind basis, no treated child had even a transient elevation of liver enzymes [11].

The level of cut-off for FPIR used in this study $(<67 \mathrm{mU} / \mathrm{l}$ ) was arbitrary, as normal FPIR is influenced by age and puberty [22]. Similarly, we do not know whether a given elevated level of ICA has equivalent prognostic significance within the age range of the subjects studied. However, the mean ages of the control subjects ( 8.9 years) and of the treated subjects (6.3 years) were similar, and the same FPIR level was used for both the control and the treated groups.

A recent report [23] described two children (ages 8 and 11 years) and one adult (age 28 years) who were also given nicotinamide in the pre-diabetes period and who progressed to insulin-dependence. The adult had already gone over two and a half years after the first-phase insulin level was below $30 \mu \mathrm{U} / \mathrm{ml}$, and had received three courses of prednisone prior to starting the nicotinamide. The eight-year-old went approximately 2 years after having a first-phase insulin below $30 \mu \mathrm{U} / \mathrm{ml}$ prior to needing to start insulin (after approximately 21 months of nicotinamide therapy). These data, in addition to the data for the subject in our study (insulin-dependent after 24 months of nicotinamide treatment) suggest that when treatment with nicotinamide is started late in the diabetogenic process (FPIR $<30 \mu \mathrm{U} / \mathrm{ml}$ ), it is effective only in delaying insulin-dependence rather than in preventing it.

The results of this trial demonstrate that the onset of Type 1 diabetes in humans has been delayed by the use of nicotinamide. The better response found in those with higher initial insulin release suggests that nicotinamide will be more effective given early in the course of Beta-cell destruction, and will be ineffective late in the course. How long the delay in diabetes onset will persist, and how long the nicotinamide needs to be given, are questions requiring answers. Clearly, a multicentre double-blind study of the effects of nicotinamide on the prevention of Type 1 diabetes is now indicated.

Acknowledgements. The following people have had significant input to this research: C.C.Pilcher, B.Edgar, N.Bibby, J. Ashby (Auckland) and N. Butler-Simon, G. Klingensmith, S. K. Garg, D.O'Brien and A.Green (Denver). The research was conducted with funds from the National Children's Health Research Foundation (New Zealand) and the Children's Diabetes Foundation at Denver.

\section{References}

1. Bottazzo GF, Florin-Christensen A, Doniach D (1974) Islet cell antibodies in diabetes mellitus with autoimmune polyendocrine deficiencies. Lancet II: 1279-1283

2. Tarn AC, Thomas JM, Dean BM, Ingram D, Schwarz G, Bottazzo GF, Gale EM (1988) Predicting insulin-dependent diabetes. Lancet I: 845-850

3. Srikanta S, Ganda OP, Soeldner IS, Eisenbarth GS (1985) Firstdegree relatives of patients with type 1 diabetes: islet cell antibodies and abnormal insulin secretion. $\mathrm{N}$ Engl $\mathrm{J}$ Med 313: 461-464

4. Chase HP, Voss MA, Butler-Simon N, Hoops S, O'Brien D, Dobersen MJ (1987) Diagnosis of pre-type 1 diabetes. J Pediatr 111: $807-812$

5. Srikanta S, Ganda OP, Gleason RE, Jackson RA, Soeldner JS, Eisenbarth GS (1984) Pre-type 1 diabetes linear loss of $\beta$ cell response to intravenous glucose. Diabetes 33: 717

6. Yamada K, Nonaka K, Hanafusa T, Miyazaki A, Toyoshima H, Tarui S (1982) Preventive and therapeutic effects of large-dose nicotinamide injections on diabetes associated with insulitis. Diabetes 31: 749-753

7. Elliott RB, Bibby NJ, Reddy S (1990) Dietary prevention and enhancement of diabetes in the N.O.D. mouse. In Shafir E, Vardy P (eds) Proceedings: Immunology of Diabetes 19th International Workshop. Jerusalem, p 34 (Abstract)

8. Hermitte L, Vialettes B, Atlef N, Payan MJ, Doll N, Scheimann A, Vague $\mathrm{Ph}$ (1989) High dose nicotinamide fails to prevent diabetes in BB rats. Autoimmunity 5: 79-86

9. Vague P, Vialettes B, Lassman-Vague V, Vallo JJ (1987) Nicotinamide may extend remission phase in insulin-dependent diabetes. Lancet I: 619-620

10. Vague P, Picq R, Bernal M, Lassman-Vague V, Vialettes B (1989) Effect of nicotinamide treatment on the residual insulin secretion in Type 1 (insulin-dependent) diabetic patients. Diabetologia 32 : 316-321

11. Mendola $G$, Casamitjana $R$, Gomis R (1990) Effect of nicotinamide therapy upon Beta-cell function in newly diagnosed Type 1 (insulin-dependent) diabetic patients. Diabetologia 32: 160-162

12. Chase HP, Butler-Simon N, Garg S, McDuffie M, Hoops SL, O'Brien D (1990) A trial of nicotinamide in newly diagnosed patients with Type 1 (insulin-dependent) diabetes mellitus. Diabetologia 33: 444-446

13. Chase HP, Garg SK, Klingensmith G (1990) Prediction and possible modification of the course of pre-Type 1 diabetes. Diabetes 39: 103 a (Abstract)

14. Pilcher CC, Elliott RB (1990) A sensitive and reproducible method for the assay of human islet cell antibodies. J Immunol M 129:111-117

15. Ziegler AG, Ziegler R, Vardi P, Jackson RA, Soeldner JS, Eisenbarth GS (1989) Life-table analysis of progression to diabetes of anti-insulin autoantibody-positive relatives of individuals with Type 1 diabetes. Diabetes 38: 1320-1325

16. Cox DR, Oaken D (1984) Analysis of survival data 1st edn. Chapman and Hall, London, pp 48-56

17. LeDoux SP, Hall CR, Forbes PM, Patton NJ, Wilson GL (1988) Mechanisms of nicotinamide and thymidine protection from alloxan and streptozotocin toxicity. Diabetes 37: 1015-1019

18. Uchigata Y, Yamamoto H, Nagai H, Okamoto H (1983) Effect of poly(ADP-ribose) synthetase inhibitor administration to rats before and after injection of alloxan and streptozotocin on islet proinsulin synthesis. Diabetes 32:316-318

19. Kolb H, Burkart V, Appels B, Hannenberg H, Kantwerk-Funke G, Kiesel U, Funda J, Schraermeyer U, Kolb-Bachofen V (1990) 
Essential contribution of macrophages to islet cell destruction in vivo and in vitro. $\mathrm{J}$ Autoimmun $3: 1-4$

20. Yamada K, Miyajima E, Nonaka K (1990) Inhibition of cytokineinduced MHC class II but not class I molecule expression on mouse islet cells by niacinamide and 3-aminobenzamide. Diabetes 39: 1125-1130

21. Yamagami T, Miwa A, Takasawa S, Yamamoto H, Okamoto H (1985) Induction of rat pancreatic beta-cell tumors by the combined administration of streptozotocin or alloxan and poly (adenosine diphosphate ribose) synthetase inhibitors. Cancer Res 45: 1845-1849

22. Smith CP, Williams AJK, Thomas JM, Archibald R, Algar VD, Bottazzo GF, Gale EAM, Savage MO (1988) The pattern of basal and stimulated insulin responses to intravenous glucose in first degree relatives of Type 1 (insulin-dependent) diabetic children and unrelated adults aged $5-50$ years. Diabetologia 31 : 430-434

23. Herskowitz RD, Jackson RA, Soeldner JS, Eisenbarth GS (1989) Pilot trial to prevent type 1 diabetes: progression to overt IDDM despite oral nicotinamide. J Autoimmunity 2: 733

Received: 13 December 1990

and in revised form: 8 February 1991

Dr. H.P.Chase

Barbara Davis Center for Childhood Diabetes

UCHSC, Box B140

4200 East 9th Avenue

Denver, CO 80262

USA 